
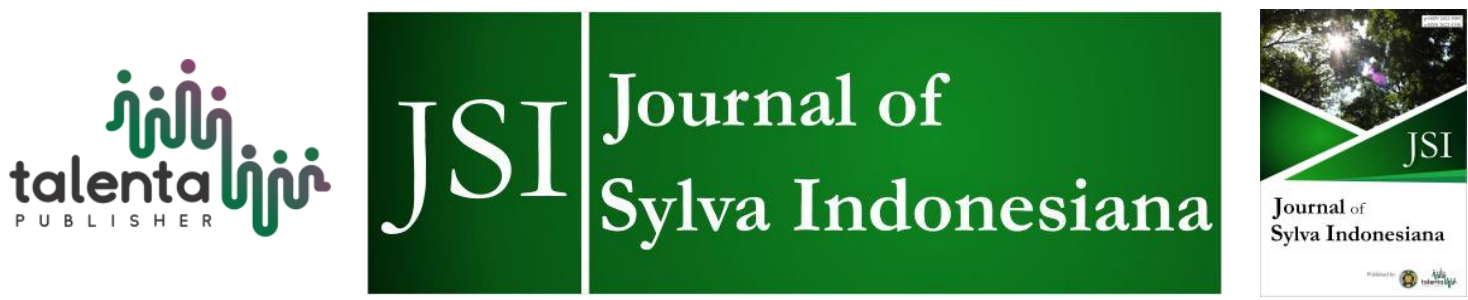

\title{
Institutional Analysis of "Gapoktan" In The Protected Forest Management Unit Area of North Kota Agung in Tanggamus Regency of Lampung Province
}

\author{
Lina Nur Aminah', Rahmat Safe' ${ }^{2}$, and Indra Gumay Febryano ${ }^{3}$ \\ ${ }^{I}$ Magister of Forestry Program, Faculty of Agriculture, Lampung University, Indonesia \\ ${ }^{2,3}$ Forestry Study Program, Faculty of Agriculture, Lampung University, Indonesia
}

\begin{abstract}
The Forest Management Unit (FMU) is the area unit of forest management which its area has been set up with clear boundaries, it has been the predominant covered by forests, it has been managed for long term including their was an explicit objective which declared in the forest management plan. FMU IX is a part of FMU area which is located in North Kota Agung. It has obtained processing area permit through CF program (CFM). CFM managed by Gapoktan (Association of Farmers Groups) who has obtained management area license. Good or bad of the CFM depends on the farmers who are incorporated in "Gapoktan" therefore research on the role of this institution is needed. This study aimed: 1) to analyze the institutional system in two Gapoktan, namely Beringin Jaya and Sinar Mulya in the boundary of CFM land in FMU IX areas of North Kota Agung, and 2) to evaluate the level of effectiveness of "Gapoktan" organization. Appeal data have been developed by the method of SSBP (situation-structure-behavior-performance). The results showed the different performance of both Gapoktan. Beringin Jaya has had good institutional situation, its organizational structure was running well, its member behavior was active in every activities, and performance was very good. Meanwhile in Sinar Mulya, its organizational structure was not going well, the activities were lack hence its performance was not satisfied. The result of the effectiveness level at Beringin Jaya was effective, on the other hand the effectiveness level at Sinar Mulya was quite effective.
\end{abstract}

Keyword: CF Management (CFM), Forest Management Unit (FMU), Gapoktan Institution, SSBP Method.

Received 29 October 2017 | Revised 11 December 2017 | Accepted 3 Pebruary 2018

\section{Introduction}

The Forest Management Unit (FMU) is the smallest unit of forest management based on its main function and allocation, which can be managed efficiently and sustainably. Castaneda in [1] defined the FMU as a designated forest management unit with clear boundaries, most of

\footnotetext{
*Corresponding author at: Lampung University, Jl. Prof.Dr.Soemantri Brodjonegoro No.1, Gedong Meneng, Bandar Lampung, Indonesia 35145

E-mail address: linanuraminah@gmail.com
}

Copyright (c) 2018 Published by Talenta Publisher 
which are covered by forests, managed for the long term and have a number of clear objectives set forth in the forest management plan.

FMU consists of Conservation FMU (Kesatuan Pengelolaan Hutan Konservasi/KPHK), Production FMU (Kesatuan Pengelolaan Hutan Produksi/KPHP) and Protected FMU (Kesatuan Pengelolaan Hutan Lindung/KPHL). Conservation FMU is forest management unit which territory is entirely or dominated by conservation forest areas. Production FMU is forest management unit which territory is entirely or dominated by production forest area. Protected FMU is forest management unit which territory is entirely or dominated by protected forest areas.

The management of natural resources in the FMU area cannot be separated from the community intervention. Community access to forest resources is driven by socio-cultural conditions of society and economic expectations of communities to improve their lives. Social-economic conditions and the relatively low welfare of communities surrounding the forest areas triggered the entry of communities into forest areas to conduct illegal agricultural activities. These agricultural activities result in degradation and deforestation of forest areas. To ensure the forest sustainability, an institution that regulates how the community utilized of forest resources in the FMU is required. Institutional process plays a very important role in the success of forest management.

Lampung Province has 15 FMUs, one of which is KPHL North Kota Agung. In the beginning, the community around Protected FMU area of North Kota Agung illegally utilized forest resources in the area regardless of forest sustainability, so to overcome the problem the government issued a policy through Community Forest Management (CFM) program. CFM in the KPHL area of North Kota Agung is done by people who are members of farmer group or association of farmer group (called gapoktan), in the hope that its existence provides benefit for society. Gapoktan institutions usually contain external and internal rules in groups and sanctions that can be a control system for members in CFM in KPHL North Kota Agung.

Institutional systems applied usually vary depending on the agreement between members of gapoktan. This can distinguish the success achieved in CFM area in KPHL North Kota Agung. This study aims to compare the existing institutional system in the Gapoktan of KPHL North Kota Agung which resulted in differences in the CFM success rate.

\section{Materials and Methods}

The research was conducted at Beringin Jaya Gapoktan (located in Pekon Margoyoso, Sumberejo district) and Sinar Mulya Gapoktan (located in Pekon Sukamaju, Ulu Belu district) Tanggamus Regency, Lampung Province. The research was conducted in these locations 
because Beringin Jaya was a successful gapoktan in CFM, while Sinar Mulya has not gained any achievements. Both gapoktans were established in almost the same time.

The research was a qualitative research. Data collection was done through participant observation, in-depth interview, and document analysis. The research was conducted from January to February 2017. The 43 respondents were members of a population of 1272 people (Beringin Jaya had 571 members and Sinar Mulya had 701 members). According to Arikunto [2] if the population is more than 100 then the error limit used is $10-15 \%$. In order to better support the data, the limit error used in this study was $15 \%$. The number of respondent samples was determined using formula: $n=\frac{N}{\mathrm{~N}\left(\mathrm{e}^{\mathrm{a}}\right)+1}$

Description:

$\mathrm{n}=$ number of respondents

$\mathrm{N}=$ total number of farmers CFM area

$\mathrm{e}=$ precision $15 \%$

$n=43$ respondents

The sample was chosen by purposive method with the consideration that the selected sample was the farmer who managed the area of CFM and also member of Beringin Jaya and Sinar Mulya.

The analysis of institutional system in Beringin Jaya and Sinar Mulya was explained using situational, structure, behavior and performance (SSBP) methods. This approach aims to look at the different institutional systems that have been applied in both gapoktan and compare whether gapoktan with good situation, structure and behavior would also have good performance of the CFM. The situation and structure in an institutional system can influence each other's behavior and ultimately affect behavior and determine the performance [3].

\section{Result and Discussion}

\subsection{Characteristics of the Respondents}

Beringin Jaya and Sinar Mulya were 2 of 14 gapoktans in the CFM area in the KPHL North Kota Agung. The data of Gapoktan that had obtained permission from the government to work on CFM area in the KPHL North Kota Agung is presented on Table 1. 
Table 1 List of Gapoktan CFM in KPHL North Kota Agung

\begin{tabular}{llcr}
\hline No & Gapoktan's name & Number & Area (ha) \\
\hline 1 & KPPM & 304 & 593,579 \\
2 & KOP TAN Harapan Sentosa & 273 & 300,000 \\
3 & KOP TAN Sumber Rejeki & 275 & 499,563 \\
4 & KOP BUN Margo Rukun & 282 & 1428,700 \\
5 & Makmur & 565 & 856,600 \\
6 & Karya Tani Mandiri & 653 & 1977,600 \\
7 & Beringin Jaya & 571 & 871,000 \\
8 & Agung & 961 & 1662,640 \\
9 & Agung & 885 & 1046,730 \\
10 & Lestarai & 171 & 385,110 \\
11 & Tunas Jaya & 584 & 1264,720 \\
12 & Mandiri & 421 & 563,750 \\
13 & Binangkit & 217 & 289,1750 \\
14 & Sinar Mulya & 701 & 917,000 \\
\hline
\end{tabular}

Respondents interviewed consisted of 19 respondents from Beringin Jaya, 24 respondents from Sinar Mulya and 4 additional respondents from stakeholders involved in assisting Gapoktans (2 from North Kota Agung Consortium and 2 from KPHL North Kota Agung).

\subsection{Institutional Situation in Beringin Jaya and Sinar Mulya Gapoktans}

Beringin Jaya was an association of 8 farmer groups whose members were cultivators of 30 areas of CFM in KPHL North Kota Agung. The farmer groups associated were Lestari Jaya 1, Lestari Jaya 2, Lestari Jaya 3, Lestari Jaya 4, Lestari Jaya 5, Lestari Jaya 6, Lestari Jaya 7 and Lestari Jaya 8.Beringin Jaya was established in 2009. It received determined areal map CFM permit from the Minister of Forestry in 2013 with decree number SK.886.Menhut-II.2013. In 2014, Gapoktan Beringin Jaya received CFM processing area permit in protected forest area in Tanggamus Regency from Tanggamus Regent with decree number B.465 / 34 / II / 2014. The permit was covering 871 ha area and involving 571 head of families.

Sinar Mulya consisted of 8 (eight) farmers group CFM area namely Delong Selatan, Delong Tengah, Delong Utara, Lungur Buntung, and Pondok Rejofarmer groups. Sinar Mulya was established in 2009 and had obtained determined areal map CFM permit from the Minister of Forestry in 2013 with decree number SK.80.Menhut-II.2014. In 2014 this Gapoktan received the CFM processing area permit in 39 registers North Kota Agung from Regent Tanggamus with decree No.B.461/34/I//2014. The permit was covering 917 ha area.

The establishment of Beringin Jaya and Sinar Mulya was based on the similarity passion of the farmers to improve their living standard and family income. Before the Gapoktan existed, these farmer groups did not run maximally. The Consortium of North Kota Agung (KORUT), KPHL North Kota Agung, Indonesian Forestry Extension Institute (IPKINDO), CFM Forum (consisting of Gapoktan group officials) and community-based forestry instructors (called 
PKSM) supported the farmers' objective and provided assistance to establish Beringin Jaya and Sinar Mulya in 2009.

The establishment process of these two Gapoktans determined the strength of the group. Their survival to date depends heavily to the participation of stakeholders (KORUT, IPKINDO, PKSM and CFM Forum) in providing assistance.

Assistance from the stakeholders involved has a positive impact on Gapoktans. Beringin Jaya is a modeled Gapoktan at KPHL North Kota Agung, so it obtains more attention compared to Sinar Mulya and the others.

\subsection{Institutional Structure in Beringin Jaya and Sinar Mulya}

Structure is an institutional alternative in which the stakeholders can choose to arrange various things in a system [3]. The structure referred to in this study refers to the definition of structure that describes the rules, norms or values of life and prevailing culture [4]. The rules in this case are a shared set of understandings about what is or may not be done where the rules can be enforced and monitored by organizations or parties that have the authority to impose sanctions on every rule violator.

The organizational structure in Beringin Jaya consisted of chair, vice chair, secretary, second secretary, treasurer, second treasurer, conservation officer, instructor, economic officer, spiritual officer, research and development ( $\&$ \& $)$, forest security and protection officer (called Pamhut), socio-cultural officer, and livestock officer. They were selected by member deliberation.

Each group belonging to Gapoktan had the same organizational structure. The chairman, deputy, secretary and treasurer in the groups also share the same functions. In addition, Beringin Jaya also had the management structure of the cooperative Beringin Jaya, with the persons in charge were member outside the Gapoktan management to prevent the interference of interests.

The interview we conducted showed that institutional structure of Beringin Jaya worked well. Each persons performed their duties in accordance with applicable rules. They realized that they are the driving force in the Gapoktan and had greater responsibility for Gapoktan and its members. The good structure of Gapoktan made the institutional went well, because all activities are well organized. The applicable informal rule in Beringin Jaya was presented in Table 2.

The organizational structure of Sinar Mulya was similar to Beringin Jaya. They also had administrators such as chairman, vice chairman, secretary, and treasurer. Despite having similar situation and structures, their levels of success were different. Some of Sinar Mulya's administrators did not fulfill their responsibility as Gapoktan boards, causing members to feel 
the institutional structure was not working well. In addition, not all members were included in the activities so the information was not evenly distributed.

Structures and situations affected the behavior of Human Resources (HR) which further affect the performance of human resources [4]. The lack of institutional instability in Sinar Mulya was not only caused by institutional structure that is not working well, but also due to the lack of intensive support from KPHL and from the stakeholders involved.

Based on the results of interviews with Gapoktan companions (KORUT, IPKINDO and PKSM), their lack of intensive assistance in Sinar Mulya was caused by the lack of budget to conduct mentoring activities. In contrast to Beringin Jaya, which was used as a model by KPHL North Kota Agung and always involved in any activities related to CFM.

The assistance activity of Beringin Jaya was more intensive than other Gapoktan. Less activeness of Sinar Mulya also caused by the many activities outside the forestry sector such as coffee farming.

Table 2 The informal rules in Beringin Jaya

\begin{tabular}{lll}
\hline No & Informal rules & \multicolumn{1}{c}{ Description of Regulation } \\
\hline 1 & $\begin{array}{l}\text { Paying } \\
\text { obligatory fee }\end{array}$ & - Annual obligatory fee is Rp. 80,000 \\
2 & $\begin{array}{l}\text { Attend monthly } \\
\text { meetings }\end{array}$ & $\begin{array}{l}\text { - The meetings provide information related to the activities being } \\
\text { carried out by Gapoktan } \\
\text { - Discussing the planned activities to be undertaken } \\
\text { - Solving problems by deliberation }\end{array}$ \\
3 & $\begin{array}{l}\text { Keep the } \\
\text { reputation of } \\
\text { Gapoktan }\end{array}$ & $\begin{array}{l}\text { - All members must keep and promote the reputation of Gapoktan } \\
\text { by being an honest and achieving farmerof CFM area }\end{array}$ \\
4 & $\begin{array}{l}\text { Equality right of } \\
\text { speech for every } \\
\text { member }\end{array}$ & $\begin{array}{l}\text { - Each member has the right to express his or her opinion relating } \\
\text { to the CFM area for the good and benefit of Gapoktan }\end{array}$ \\
$\begin{array}{l}\text { Gapoktan shall } \\
\text { comply with } \\
\text { applicable } \\
\text { restrictions and } \\
\text { sanctions. } \\
\text { Same treatment } \\
\text { for every } \\
\text { member }\end{array}$ & $\begin{array}{l}\text { - Each member shall comply with applicable restrictions and } \\
\text { sanctions. In the event of violation, members willing to accept } \\
\text { sanctions set by members in member meetings }\end{array}$ \\
\end{tabular}

The structure of the study was also include norms or values as well as what should and should not be done. Beringin Jaya imposed sanctions on members who violate the established rules. The sanctions set by Beringin Jaya were similar to the sanctions set by Sinar Mulya. Such rules and sanctions were: 
1. Prohibition of harvesting live timber and catching protected animals

2. Prohibition of expanding or clearing forests, either productive or non-productive

3. Prohibition of protecting activities that harm the group

4. Prohibition of stealing and harvesting loot

5. Prohibition for members who are not registered in the Decree of the Regent and Minister to work inside management area of Gapoktan

6. Prohibition on transfer of arable land.

7. Prohibited for community outside the region to work inside management area of Gapoktan

8. Prohibition of making problems and provoking members of farmer groups

9. Prohibition of vigilante

10. Prohibition of burning forest area

11. Violating the prohibition number 1 to 10 will get a sanction

12. Sanctions consist of three stages, if obtained by all three, will be excluded from the membership and must leave the arable land.

13. The next sanction is a legal process

14. The sanctions have been enacted in Beringin Jaya. Sinar Mulya has not been enacted the sanction so the members were not deterred to repeat the same mistakes.

\subsection{Behavior of Members, Managers and Stakeholders}

Almost $100 \%$ members of Beringin Jaya, were actively involved. The activities that have been done in Beringin Jaya were:

\section{A. $\quad$ Plot mapping}

The plot mapping was a part of the Gapoktan strengthening process carried out in a participatory manner in the hope that the cultivators understand their area limits. Plot mapping will be the database to know the area managed by members. Mapping activities conducted from May to October 2014. The stages in making a plot map were (a) Socialization of plot maps to members, (b) Participatory mapping, (c) Digitizing maps, (d) Consultations, (e) Finalization of plot maps.

\section{B. Strengthening the CF boundary}

In order to clarify the boundaries of CFM area Beringin Jaya held boundary strengthen for its members. This activity was conducted in June 2015 assisted by Gapoktan mentors. The stages performed in the activity are as follow:

1. Coordination and establishment of boundary committees. The committees in this activity were the Forest Area Gazettement Service (Balai Pemantapan Kawasan Hutan/BPKH), Province Forestry Office, KPHL North Kota Agung, group members and non-governmental organizations (NGOs) Assistance. 
2. Setting a boundary. The making of the boundary was done by involving group members, group administrators and Gapoktan.

3. Installation of the boundary. Installation of the boundary in the area of Beringin Jaya was carried out independently and involved all elements of Gapoktan in its implementation.

\section{Strengthening Gapoktan Institution}

In the effort to restore the function of forest area for the welfare of the community of CFM in the work area of Gapoktan Beringin Jaya, Gapoktan feels the need to conduct an activity as an effort to strengthen the institute which done to synergize the program or activity with the related stakeholders. The activities that have been done in an effort to strengthening Gapoktan institutions are as follows:

1. Organizational and financial management training, this activity was conducted in May 2015. With the training, the group now has a better financial system than before.

2. Assistance to the management of financial organizations. Through these activities, currently Gapoktan Beringin Jaya can run and organize finances with a standard financial system.

3. Regular meeting of Gapoktan. In Gapoktan Beringin Jaya, it is agreed to meet regularly every month.

Meeting with stakeholders. The realization of sustainable forests and prosperous communities can not be separated from the participation and support of the stakeholders, for that Gapoktan realize the need for regular meetings between members of Gapoktan and administrators with stakeholders involved in the CFM to synergize the program activities.

\section{Increasing the Economy of Members}

In an effort to improve the economy of Beringin Jaya members, the activity to strengthen of member's economy was conducted. The activities are as follows:

\section{The establishment and Strengthening of Economic Institutions}

The establishment of a medium in an effort to increase the economics of CFM members was one of the great goals of the CFM program. Some of the activities that had been done for the establishment and strengthening of economic institutions in Beringin Jaya are as follows:

a) Cooperative management training. This training had been conducted twice, in March 2013 and May 2015, involving group managers and administrators of Beringin Jaya.

b) The all-round cooperative business Beringin Jaya was established in May 2015 .

c) Cooperative mentoring. The cooperative is now running well due to the accompanying relevant stakeholders.

d) Product marketing. The cooperative in Beringin Jaya helps to increase the member's economy. Now the members are able to produce and market a wide range of non-timber forest products from CFM area. 


\section{Optimization of Coffee, Banana and Avocado Products}

The quality of coffee produced by members of Beringin Jaya in general is still below the standard, so intensification and management of post-harvest are required. The activities has been done in Gapoktan were coffee cultivation field education and post-harvest mentoring. Bananas and avocados are very helpful to increase the income when coffee is not producing. Therefore, the optimization efforts of bananas and avocados production need to be done. Training related to the cultivation of banana and avocado plants was held in May 2015.

\section{Nutmeg Cultivation}

Not only has high economic value, the nutmeg plant is quite supportive in the effort of soil conservation and biodiversity. Therefore, the Beringin Jaya Gapoktan will try to cultivate nutmeg plants. Gapoktan plans to apply for a loan to the Ministry of Environment and Forestry through the Public Service Center of Forest Development Financing Center (called BLU Pusat $\mathrm{P} 2 \mathrm{H})$ as a capital provider for seed supply and nutmeg care.

\section{E. Security and Protection.}

In addition to activities for the development of human resources (HR), Beringin Jaya also conducted forest security and protection activities from illegal logging, encroachment, poaching and fire. Pamhut incorporated in Beringin Jaya and has been given training and provided with supporting facilities and infrastructures. Pamhut patrols in Gapoktan working area according to the predefined schedule.

Unlike Beringin Jaya, Sinar Mulya has not conducted many activities. In order to apply for CFM permit, participatory mapping was done at the beginning of Sinar Jaya establishment in 2009. Other activities were high canopy tree planting in CFM area, coffee cultivation training, and routine patrol by forest protection team on CFM area. Sinar Mulya's current activity is ecotourism development of waterfall of rainbow basin, cooperating with the Department of Tourism, Forest Service, Protected FMU, and Pekon Suka Maju. Income derived from the waterfall ecotourism is divided and submitted to operational activities, Pekon Suka Maju and CFM. Revenue from ecotourism development will be capitalized by CFM for the establishment of Sinar Mulya CFM Cooperative.

\subsection{The Performance of Gapoktan}

Human resource development well implemented in productive organizations can directly contribute to improvement of performance and achievement of organizational goals [5-7]. The above opinion is in accordance with what has been done by Beringin Jaya. Beringin Jaya is actively building human resources, making its members have a better ability in terms of CFM. The ability is then used to develop the institution and it made Beringin Jaya received an award as the best CFM area manager from the Ministry of Environment and Forestry in 2016. 
The election of Beringin Jaya as the best Gapoktan cannot be separated from the good institutional system. The award earned still provides a lot of benefits for Beringin Jaya such as obtaining grants or long-term loans as support. The programs have been received such as Community Nursery and social funds. Beringin Jaya is currently applying for loan to Ministry of Environment and Forestry for their on-farm program.

Sinar Mulya is one of the pioneering Gapoktan to be as develop as Beringin Jaya. Although Sinar Mulya is still at a developing stage and its performance has not been very successful, the managers are now beginning to active and the Gapoktan is expected to go forward and develop. Sinar Mulya is planning to develop the waterfall ecotourism which can give a good impact for all members.

\section{Conclusion}

The situation, structure and behavior within an institution can affect the performance of a Gapoktan. Beringin Jaya has good institutional situation or condition. Its organizational structure within runs as it functions. Each member actively participates in activities related to Gapoktan. This is what makes Gapoktan Beringin Jaya get good results or performances. The situation of Sinar Mulya is good because it already has a clear legality, but the organizational structure in its institution is not running well. It causes the members become inactive in Gapoktan related activities, so their performance is not as good as Beringin Jaya.

\section{REFERENCES}

[1] F. Castaneda, "Why national and forest management unit level criteria and indicators for sustainable management of dry forests in Asia," Development of National-level Criteria and Indicators for the Sustainable Management of Dry Forests in Asia: Background Papers, 2000.

[2] S. Arikunto, Research Procedures A Practice Approach, Jakarta: Rineka Cipta, 2000.

[3] A. A. Schmid, Conflict and cooperation: institutional and behavioral economics: Blackwell Publishing, 2004.

[4] V. Ostrom, and E. Ostrom, "Public Goods and Public Choices," Elinor Ostrom and the Bloomington School of Political Economy: Resource Governance, D. H. Cole, M. D. McGinnis, G. Arnold, W. Blomquist, M. Cox, R. Gardner, E. Ostrom, V. Ostrom, E. Schlager and S. Villamayor-Tomas, eds.: Lexington Books, 2015.

[5] S. Brown, and J. Bessant, Strategic operations management, London Routledge, 2013.

[6] R. Q. Danish, and A. Usman, "Impact of reward and recognition on job satisfaction and motivation: An empirical study from Pakistan," International journal of business and management, vol. 5, no. 2, pp. 159-167, 2010.

[7] R. A. Swanson, and D. E. Arnold, "Part one: What is the purpose of human resource development? The purpose of human resource development is to improve organizational performance," New Directions for Adult and Continuing Education, no. 72, pp. 13-19, 1996. 